\title{
Olmesartan Induces Renoprotective Effects by Stimulating Angiotensin Type 2 Receptors and Reducing Oxidative Stress in Diabetic Nephropathy
}

\author{
Fusakazu Jo Satoshi Morimoto Mitsutaka Nakahigashi Makiko Kusabe \\ Kazunori Someya Tatsuyori Morita Hiromi Jo Takanobu Imada \\ Atsushi Kosaki Nagaoki Toyoda Mitsushige Nishikawa Toshiji Iwasaka \\ Second Department of Internal Medicine, Kansai Medical University, Moriguchi City, Japan
}

\section{Key Words}

Angiotensin receptor blocker - Angiotensin type 1 receptor . Angiotensin type 2 receptor $\cdot$ Blood pressure .

Renin-angiotensin system · Streptozotocin • Urinary protein

\begin{abstract}
Background: Angiotensin receptor blockers reduce the progression of diabetic nephropathy primarily by inhibiting angiotensin type $1\left(\mathrm{AT}_{1}\right)$ receptors. In the present study, we investigated the role of angiotensin type $2\left(A_{2}\right)$ receptors on the renoprotective effects of olmesartan in diabetic nephropathy. Methods: Six-week-old mice were treated with streptozotocin and divided into four groups: the OLM group (mice treated with olmesartan), the OLM+Ang II group (mice treated with olmesartan and angiotensin II), the OLM+PD group (mice treated with olmesartan and the $\mathrm{AT}_{2}$ antagonist PD 123319), and the vehicle group. Nondiabetic mice were used as controls. We measured blood glucose levels and urinary excretions of albumin and 8-hydroxy-2'-deoxyguanosine $(8-\mathrm{OHdG})$, which is a marker for oxidative stress. $\boldsymbol{R e}$ sults: Although urinary albumin excretion in the OLM and OLM+Ang II groups showed a tendency to be reduced compared to the vehicle group, it was significantly lower com-
\end{abstract}

pared to the OLM+PD group. Urinary excretion of 8-OHdG was also significantly lower in the OLM and OLM+Ang II groups compared to the OLM+PD group. Conclusions: In diabetic nephropathy, the renoprotective effects of olmesartan are due not only to the blockade of $\mathrm{AT}_{1}$ receptors, but also to a reduction in oxidative stress via stimulation of $A T_{2}$ receptors.

Copyright $\odot 2011$ S. Karger AG, Basel

\section{Introduction}

Diabetic nephropathy is the leading cause of end-stage renal disease in industrialized countries [1]. Because of the clinical and economic burden of diabetic nephropathy, there have been considerable efforts to identify ways to prevent or delay its progression. Current research suggests that the aggressive lowering of blood pressure is essential for achieving maximal renal protection in diabetic nephropathy [2]. In addition, several clinical trials have shown that agents that block the renin-angiotensin system may have better renoprotective effects than other antihypertensive classes. Moreover, compared to background treatment with conventional agents, angiotensin-

\section{KARGER}

Fax +41613061234 E-Mail karger@karger.ch www.karger.com

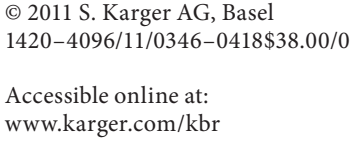

Fusakazu Jo, MD

Second Department of Internal Medicine, Kansai Medical University

10-15 Fumizono-cho

Moriguchi City 570-8506 (Japan)

Tel. +81 66992 1001, E-Mail jof@takii.kmu.ac.jp 
converting enzyme inhibitors and angiotensin receptor blockers have been found to delay the progression from microalbuminuria to macroalbuminuria in diabetic patients $[3,4]$ and reduce the incidence of end-stage renal disease in patients with diabetic nephropathy $[5,6]$.

Angiotensin II has two major receptor isoforms, type $1\left(\mathrm{AT}_{1}\right)$ and type $2\left(\mathrm{AT}_{2}\right)$ receptors [7], and both receptors are expressed in adult human kidneys [8]. Angiotensin receptor blockers prevent the binding of angiotensin II to $\mathrm{AT}_{1}$ receptors and increase the levels of angiotensin II, which could potentially induce signaling through $\mathrm{AT}_{2}$ receptors [9]. $\mathrm{AT}_{2}$ receptors have been reported to mediate angiotensin II actions that oppose $\mathrm{AT}_{1}$ receptor effects in the vasculature [10-12]. The role of $\mathrm{AT}_{2}$ receptors in diabetic nephropathy, however, remains poorly defined. Therefore, the present study investigated the role of $\mathrm{AT}_{2}$ receptors on the renoprotective effects of olmesartan in a diabetic nephropathy mouse model.

\section{Methods}

\section{Animal Model}

The present study examined 6-week-old male C57BL6/J mice (Shimizu Exp. Co., Kyoto, Japan). All animals were housed in a temperature- and humidity-controlled room with a 12-hour light/dark cycle and were fed standard laboratory animal chow. In addition, they had free access to tap water.

\section{Induction of Diabetic Nephropathy}

Diabetes was induced by a single intraperitoneal injection of streptozotocin (STZ, $200 \mathrm{mg} / \mathrm{kg}$ body weight; Sigma Chemical Co., St. Louis, Mo., USA) diluted in sodium citrate buffer ( $\mathrm{pH} 4.5$, $50 \mathrm{mmol} / \mathrm{l})$. Seven days after the STZ injection, nonfasted animals were anesthetized with isoflurane to reduce the stress involved in blood collection. A 5-mm section of the tail tip was cut, blood was exposed to One Touch glucose test strips (Johnson \& Johnson, New Brunswick, N.J., USA), and the glucose levels were displayed on a One Touch II blood glucose meter. STZ-treated animals with mean nonfasted blood glucose levels $>300 \mathrm{mg} / \mathrm{dl}$ were determined to be diabetic; all others were excluded from the study.

\section{Grouping}

The diabetic mice were divided into four groups: (1) the OLM group, which consisted of diabetic mice treated with the $\mathrm{AT}_{1}$ antagonist olmesartan (3 mg/kg/day; Daiichi-Sankyo Co., Tokyo, Japan); (2) the OLM+Ang II group, which consisted of mice treated with olmesartan and angiotensin II (1,000 ng/kg/min; Peptide Institute, Osaka, Japan); (3) the OLM+PD group, which consisted of mice treated with olmesartan and the $\mathrm{AT}_{2}$ receptor antagonist PD 123319 (30 mg/kg/day; Sigma Chemical Co.); and (4) the vehicle group (mice treated with sodium bicarbonate water). Nondiabetic mice were used as controls (nondiabetic control group). All drugs were delivered via an osmotic minipump (Alza and part of the DURECT Corp., Cupertino, Calif., USA) 8-10 weeks after the STZ injection.

Effects of Olmesartan on Diabetic Nephropathy

\section{Animal Analysis}

At 2, 4, 6, 8 and 10 weeks after the STZ injection, individual mice were separately housed in metabolic cages (Shinano Manufacturing, Tokyo, Japan) for $24 \mathrm{~h}$ to collect urine. After the urine volume was measured, we examined the levels of urine albumin and urine 8-hydroxy-2'-deoxyguanosine (8-OHdG; an oxidative stress marker) [13] by SRL (Okayama, Japan). Body weight, blood pressure and blood samples were also measured at the same time.

Systolic blood pressure (sBP) was measured using a computerized tail-cuff system (BP-2000, Visitech Systems, USA) in conscious animals. After the mice were trained for 3 consecutive days with the prewarmed tail-cuff device to acclimate them to the procedure, we measured sBP and heart rate on 3 consecutive days. On each day of blood pressure testing, 20 measurements were obtained and averaged for each mouse. The mean values of all 3 days were used for comparison. Blood samples were obtained from the retro-orbital sinus under isoflurane anesthesia, and blood urea nitrogen, serum creatinine, serum albumin and serum total protein were measured by SRL. Eight weeks after the STZ injection, the osmotic minipumps were implanted in the mice. The data were analyzed for statistical significance using commercial software.

\section{Statistics}

All data are expressed as means \pm SEM. Groups of samples were compared using an independent $t$ test or repeated measures analysis of variance, as appropriate.

\section{Results}

Approximately $20 \%$ of the animals failed to show blood glucose levels $>300 \mathrm{mg} / \mathrm{dl}$ and were excluded from the study. Figure 1 shows that the serum glucose levels of the nondiabetic control mice remained $<200 \mathrm{mg} / \mathrm{dl}$. Serum glucose levels were significantly higher after 2 weeks in the diabetic mice than in the nondiabetic control mice. Urinary albumin excretion for $24 \mathrm{~h}$ was significantly higher after 2 weeks in the diabetic mice compared to the nondiabetic control mice (fig. 2), which indicates that our diabetic nephropathy model was appropriate for this study. In addition, urinary 8-OHdG excretion was significantly increased after 2 weeks in the diabetic mice compared to the nondiabetic control mice (fig. 3).

Eight weeks after the STZ injection, the mice in each group were treated with the appropriate drugs via minipump. Table 1 shows changes in parameters in each group. Body weight was lower in each diabetic group compared to the nondiabetic control mice. Irrespective of treatment, urinary volume was significantly higher in the diabetic mice than in the nondiabetic control mice. There were no significant differences in urinary volume between the diabetic groups. In addition, there were no differences between total protein and serum albumin between these groups. 


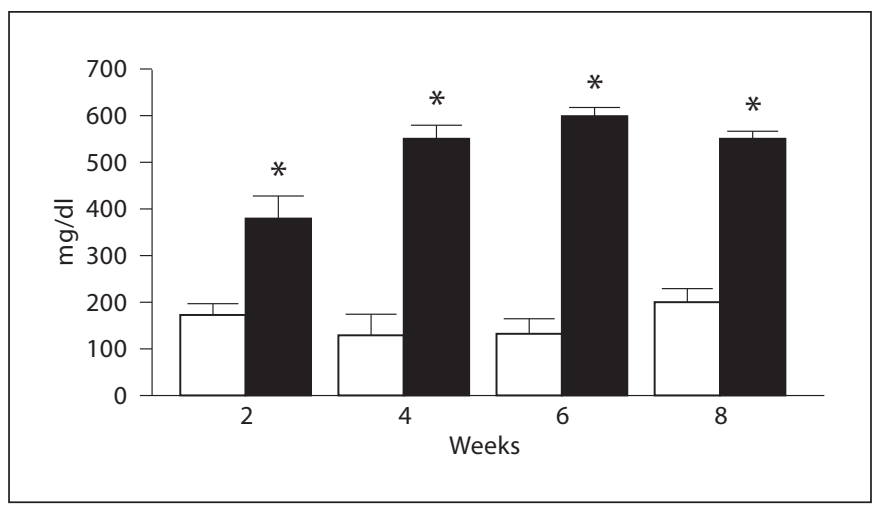

Fig. 1. Changes in serum glucose after STZ injection. Open bar: nondiabetic control mice $(\mathrm{n}=7)$; closed bar: diabetic mice $(\mathrm{n}=$ 48). ${ }^{*} \mathrm{p}<0.001$ vs. nondiabetic control mice.

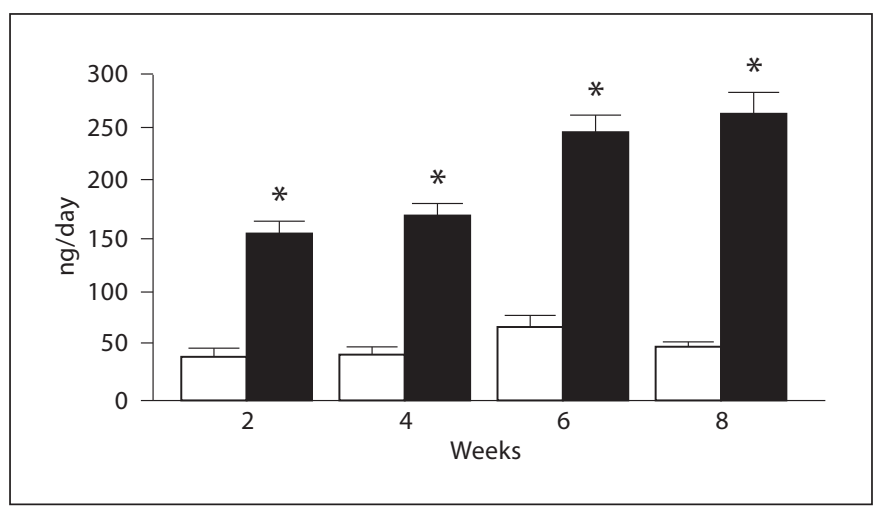

Fig. 3. Changes in urinary $8-\mathrm{OHdG}$ excretion for $24 \mathrm{~h}$ after STZ injection. Open bar: nondiabetic control mice $(n=5)$; closed bar: diabetic mice $(\mathrm{n}=47) .{ }^{*} \mathrm{p}<0.0005$ vs. nondiabetic control mice.

Figure 4 shows the sBP measurements at week 10 (2 weeks after the start of medication). Compared to the vehicle group, sBP was significantly lower in the OLM group, the OLM+Ang II group and the OLM+PD group; however, sBP was not significantly different between the OLM, OLM+Ang II and OLM+PD groups.

Figure 5 shows the percent change in urinary albumin excretion from the 8th week to the 10th week. Although there was no significant difference, the percent change in urinary albumin excretion showed a tendency to be decreased in the OLM group compared to the vehicle group. In addition, the percent change in urinary albumin excretion was significantly greater in the OLM+PD group than in the OLM group, but there was no significant difference between the OLM+Ang II group and the OLM group.

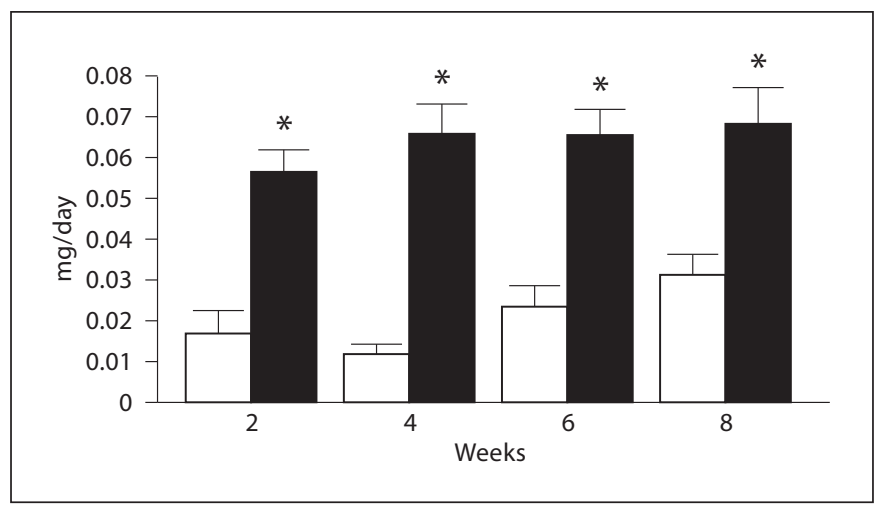

Fig. 2. Changes in urinary albumin excretion for $24 \mathrm{~h}$ after STZ injection. Open bar: nondiabetic control mice $(n=7)$; closed bar: diabetic mice $(\mathrm{n}=48) .{ }^{*} \mathrm{p}<0.005$ vs. nondiabetic control mice.

Table 1. Changes in parameters in each group

\begin{tabular}{|c|c|c|}
\hline & $\begin{array}{l}\text { Before treatment } \\
\text { ( } 8 \text { weeks after } \\
\text { STZ injection) }\end{array}$ & $\begin{array}{l}\text { After treatment } \\
\text { (10 weeks after } \\
\text { STZ injection) }\end{array}$ \\
\hline \multicolumn{3}{|l|}{ Body Weight, $g$} \\
\hline Nondiabetic control $(\mathrm{n}=7)$ & $36.7 \pm 1.0$ & $27.7 \pm 1.8$ \\
\hline Vehicle $(n=12)$ & $22.3 \pm 2.5^{*}$ & $23.5 \pm 2.8^{*}$ \\
\hline OLM $(n=13)$ & $23.1 \pm 2.1^{*}$ & $24.6 \pm 2.5^{*}$ \\
\hline OLM+Ang II $(\mathrm{n}=13)$ & $23.1 \pm 2.4^{*}$ & $24.7 \pm 2.6^{*}$ \\
\hline $\mathrm{OLM}+\mathrm{PD}(\mathrm{n}=10)$ & $20.7 \pm 1.7^{*}$ & $21.8 \pm 2.8^{*}$ \\
\hline \multicolumn{3}{|l|}{ Urinary volume, $\mathrm{ml} /$ day } \\
\hline Nondiabetic control $(n=7)$ & $1.2 \pm 0.6$ & $0.9 \pm 1.0$ \\
\hline Vehicle $(\mathrm{n}=12)$ & $16.3 \pm 5.5^{*}$ & $17.6 \pm 8.0^{*}$ \\
\hline $\operatorname{OLM}(\mathrm{n}=13)$ & $15.2 \pm 6.9^{*}$ & $17.6 \pm 10.8^{*}$ \\
\hline OLM+Ang II $(\mathrm{n}=13)$ & $19.9 \pm 9.3^{*}$ & $17.3 \pm 8.0^{*}$ \\
\hline $\mathrm{OLM}+\mathrm{PD}(\mathrm{n}=10)$ & $25.1 \pm 7.6^{*}$ & $21.6 \pm 8.8^{*}$ \\
\hline \multicolumn{3}{|l|}{ Serum total protein, $\mathrm{mg} / \mathrm{dl}$} \\
\hline Nondiabetic control $(n=4)$ & $6.0 \pm 0.8$ & $5.6 \pm 0.4$ \\
\hline Vehicle $(n=7)$ & $5.0 \pm 0.6$ & $5.2 \pm 0.4$ \\
\hline OLM $(n=9)$ & $5.4 \pm 1.4$ & $5.5 \pm 0.3$ \\
\hline OLM+Ang II $(n=9)$ & $5.2 \pm 0.5$ & $5.8 \pm 0.8$ \\
\hline $\mathrm{OLM}+\mathrm{PD}(\mathrm{n}=8)$ & $5.2 \pm 1.7$ & $6.2 \pm 2.4$ \\
\hline \multicolumn{3}{|l|}{ Serum albumin, $\mathrm{mg} / \mathrm{dl}$} \\
\hline Nondiabetic control $(\mathrm{n}=4)$ & $3.7 \pm 1.0$ & $3.7 \pm 1.1$ \\
\hline Vehicle $(\mathrm{n}=7)$ & $2.4 \pm 0.3$ & $2.6 \pm 0.2$ \\
\hline OLM $(n=9)$ & $3.3 \pm 2.3$ & $2.6 \pm 0.2$ \\
\hline OLM+Ang II $(\mathrm{n}=9)$ & $2.7 \pm 0.8$ & $2.5 \pm 0.3$ \\
\hline $\mathrm{OLM}+\mathrm{PD}(\mathrm{n}=8)$ & $2.5 \pm 0.9$ & $3.3 \pm 2.6$ \\
\hline
\end{tabular}

All data are means \pm SE.

${ }^{*} \mathrm{p}<0.001$ compared with nondiabetic control group. 


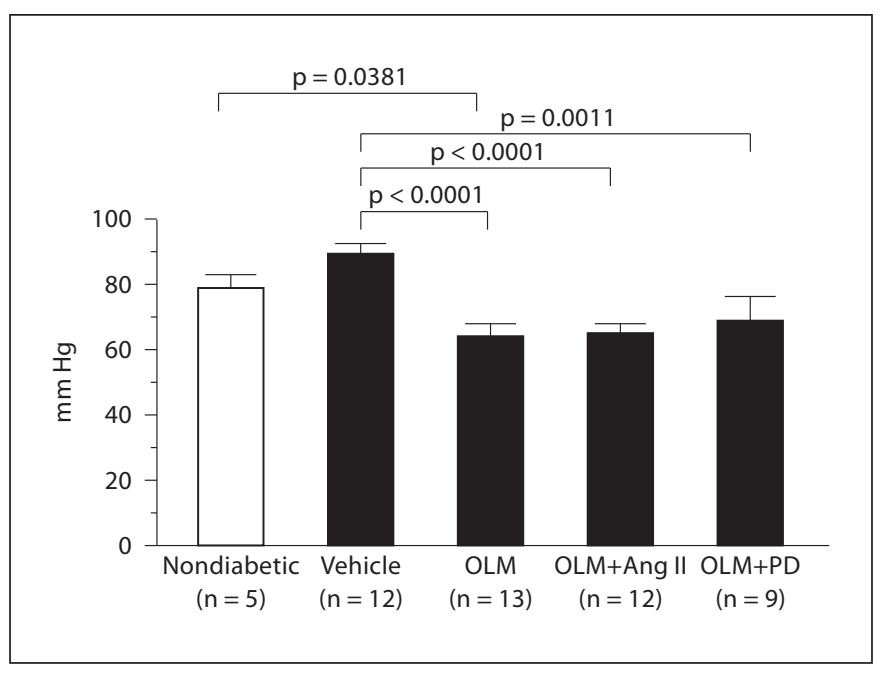

Fig. 4. Comparison of sBP levels 10 weeks after STZ (2 weeks after the start of experimental medication).

Figure 6 shows urinary 8-OHdG excretion at week 10 . Urinary excretion of 8-OHdG was significantly lower in the OLM and OLM+Ang II groups than in the vehicle group. Interestingly, the reduction of urine $8-\mathrm{OHdG}$ by olmesartan was not observed in the OLM+PD group.

\section{Discussion}

In the present study, the diabetic mice showed significantly increased urinary excretion of albumin and 8-OHdG compared to the nondiabetic control mice. Although blood pressure was significantly lower in the OLM group compared to the vehicle group, there were no significant differences between the OLM, OLM+Ang II and OLM+PD groups. The percent change in urinary albumin excretion showed a tendency to be decreased in the OLM and OLM+Ang II groups compared to the vehicle group. In addition, urinary excretion of $8-\mathrm{OHdG}$ was significantly lower in the OLM and OLM+Ang II groups than in the vehicle group. There was no significant difference, however, between the OLM+PD group and the vehicle group. These results suggest that the renoprotective effects of olmesartan are due, at least in part, to a reduction in oxidative stress via the stimulation of $\mathrm{AT}_{2}$ receptors in diabetic nephropathy.

Diabetic nephropathy is a common cause of end-stage renal disease in industrialized countries [1]. Its characteristic features are albuminuria and structural alterations, such as a thickened glomerular basement membrane and

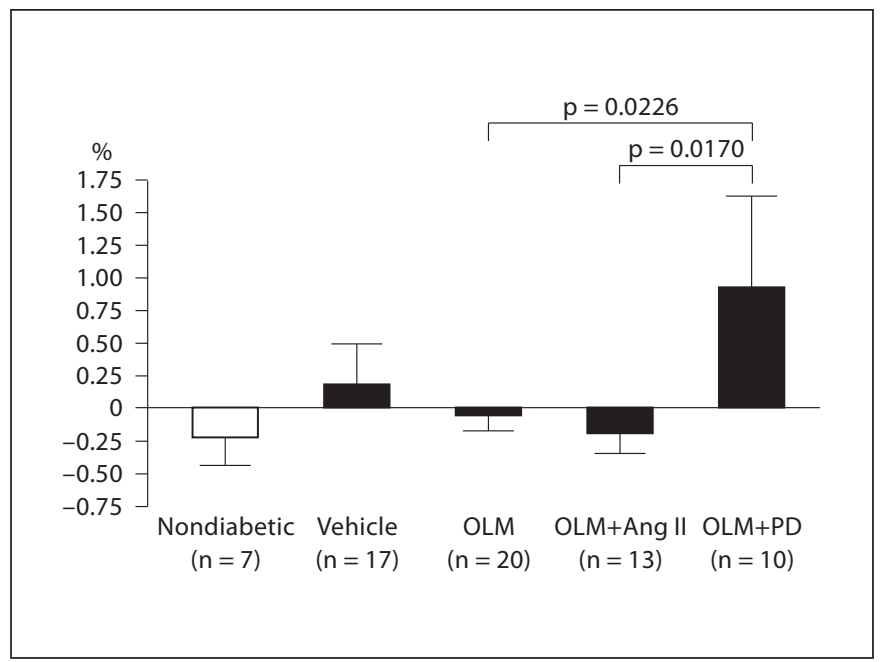

Fig. 5. Comparison of the percent change in urinary albumin excretion from the 8 th to the 10 th week after STZ injection.

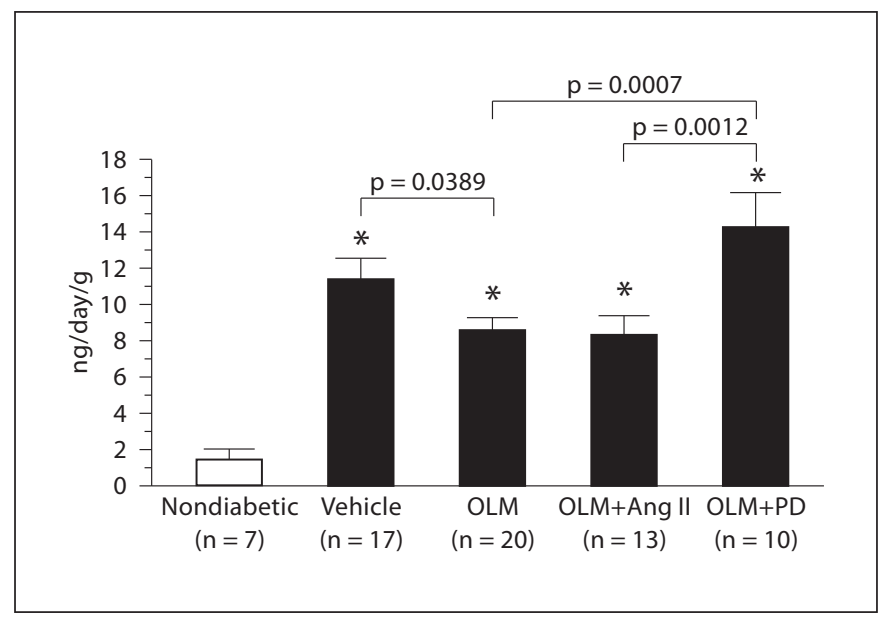

Fig. 6. Comparison of urinary 8-OHdG excretion 10 weeks after STZ injection (2 weeks after the start of experimental medication). ${ }^{*} \mathrm{p}<0.005$ vs. nondiabetic control mice.

the progressive accumulation of extracellular matrix proteins in the glomerular mesangium [14]. Despite several recent advances, the mechanisms responsible for this disease have not been fully identified.

The renin-angiotensin system plays an important role in the cardiovascular system [15], and all components of the renin-angiotensin system are also present in the kidneys [16]. In addition, $\mathrm{AT}_{1}$ receptors are expressed in the afferent and efferent arterioles, glomeruli and proximal tubules [17]. Almost all classical angiotensin II-induced 
functions, such as vasoconstriction, sodium and water reabsorption, as well as increased cellular hypertrophy, proliferation and extracellular matrix deposition in the kidney, are mediated by $\mathrm{AT}_{1}$ receptors. Experimental [18] and clinical [19] studies with ARBs have indicated that $\mathrm{AT}_{1}$ receptors are involved in the progression of renal disorders.

Expression of the $\mathrm{AT}_{2}$ receptor is high during fetal development and then declines with age. $\mathrm{AT}_{2}$ receptors are still expressed in the adult kidney, however, and are mainly localized in the interlobular arteries [8], proximal tubules, collecting ducts, renal interstitial cells, arcuate arteries, afferent arterioles and outer medullary descending vasa recta $[20,21]$. These strategic renal locations suggest an involvement of the $\mathrm{AT}_{2}$ receptors in the regulation of renal hemodynamic and tubular functions. Although the function of $\mathrm{AT}_{2}$ receptors has not been clearly defined, activation of this receptor has been hypothesized to antagonize $\mathrm{AT}_{1}$ receptor-mediated effects, which provides a negative feedback control [22]. Activation of $\mathrm{AT}_{2}$ receptors decreases blood pressure, inhibits cell growth, induces cell differentiation and mediates apoptosis [23]. In addition, stimulation of $\mathrm{AT}_{2}$ receptors increases renal sodium and water excretion and influences renal blood flow via the induction of renal nitric oxide and cyclic GMP production [24].

Angiotensin receptor blockers prevent the binding of angiotensin II to $\mathrm{AT}_{1}$ receptors and increase levels of angiotensin II, which could potentially induce signaling through $\mathrm{AT}_{2}$ receptors [9]. Therefore, this alternate signaling via $\mathrm{AT}_{2}$ receptors could represent an additional mechanism of renoprotection by ARBs. The role of $\mathrm{AT}_{2}$ receptors in the renoprotective effects of $A R B s$ remains poorly defined, however. Therefore, the present study investigated the role of $\mathrm{AT}_{2}$ receptors in the renoprotective effects of olmesartan in a diabetic nephropathy mouse model. Although blood pressure was significantly lower in the OLM group compared to the vehicle group (fig. 4), blood pressure was not significantly different between the OLM, OLM+Ang II and OLM+PD groups. We hypothesized that neither the stimulation of $\mathrm{AT}_{2}$ receptors by exogenous angiotensin II nor the inhibition of $\mathrm{AT}_{2}$ receptor stimulation could affect blood pressure when $\mathrm{AT}_{1}$ receptors are blocked. In contrast, the percent change in urinary albumin excretion showed a tendency to be decreased in the OLM group compared to the vehicle group. Interestingly, the decrease in percent change in urinary albumin excretion by the OLM group disappeared in the OLM+PD group, but not in the OLM+Ang II group (fig. 5). We hypothesized that stim- ulation of $\mathrm{AT}_{2}$ receptors may account, at least in part, for the renoprotective effects of olmesartan regardless of blood pressure changes. In contrast, stimulation of type 2 receptors without $A R B s$ treatment may be negligible because PD 123319 alone did not affect blood pressure or urinary excretion of albumin in our preliminary study (data not shown). Interestingly, angiotensin II administration did not enhance the effects observed after olmesartan. This may be because the $\mathrm{AT}_{2}$ receptors were maximally stimulated by intrinsic angiotensin II after olmesartan administration. It is unlikely that the dose of angiotensin II (1,000 $\mathrm{ng} / \mathrm{kg} / \mathrm{min})$ was too low because this dose significantly increased blood pressure compared to the vehicle [sBP 2 weeks after treatment: angiotensin II ( $\mathrm{n}=3), 118 \pm 28 \mathrm{~mm} \mathrm{Hg}$; vehicle $(\mathrm{n}=12), 90$ $\pm 3 \mathrm{~mm} \mathrm{Hg}, \mathrm{p}<0.05$ ] in our preliminary experiment.

Of the various features associated with diabetes, oxidative stress has been suggested to play an important role in the pathogenesis of diabetic nephropathy because it is induced under diabetic conditions and has been known to induce cellular dysfunction in a wide variety of cells (e.g. mesangial and endothelial cells) [25]. Nuclear and mitochondrial DNA are common targets of oxidative damage, and guanine is the nucleic acid base that is most prone to oxidation, which adds a hydroxyl group at the eighth position of guanine. When damaged DNA is repaired, $8-\mathrm{OHdG}$ is produced and excreted unchanged in the urine [26]. Therefore, urinary $8-\mathrm{OHdG}$ is used as a marker of oxidative DNA damage [26]. In the present study, diabetic conditions resulted in increased oxidative stress, which was determined by the urinary excretion of 8-OHdG (fig. 3). Interestingly, the urinary excretion of 8-OHdG was significantly lower in the OLM group compared to the vehicle group (fig. 6). The reduction of urine 8 -OHdG by olmesartan disappeared in the OLM+PD group, but not in the OLM+Ang II group. We hypothesized that olmesartan may reduce oxidative stress by stimulating $\mathrm{AT}_{2}$ receptors. Nagasu et al. [27] reported that olmesartan suppressed the oxidative stress caused by activation of $\mathrm{NAD}(\mathrm{P}) \mathrm{H}$ oxidase in glomeruli in SHR/ NDmcr-cp rats, an animal model of metabolic syndrome. In addition, Takao et al. [28] have shown that olmesartan and valsartan reduced $\mathrm{NAD}(\mathrm{P}) \mathrm{H}$ oxidase activity and decreased oxidative stress in human renal proximal tubular epithelial cells damaged by albumin. Therefore, it is possible that stimulation of $\mathrm{AT}_{2}$ receptors by ARBs may inhibit NAD $(\mathrm{P}) \mathrm{H}$ oxidase to reduce oxidative stress. Further studies are required to prove this hypothesis. 
In conclusion, the results of the present study suggest that stimulation of $\mathrm{AT}_{2}$ receptors and reduced oxidative stress contribute to the renoprotective effects of the angiotensin receptor blocker olmesartan in diabetic nephropathy. Further studies are needed to determine whether these findings are specific to olmesartan or common to the whole class of angiotensin receptor blockers. In addition, future studies should examine whether protective effects are observed in other kidney diseases.

\section{References}

$\checkmark 1$ Ritz E, Orth SR: Nephropathy in patients with type 2 diabetes mellitus. N Engl J Med 1999;341:1127-1133.

-2 Sarafidis PA, Khosla N, Bakris GL: Antihypertensive therapy in the presence of proteinuria. Am J Kidney Dis 2007;49:12-26.

$\checkmark 3$ Parving $\mathrm{HH}$, Lehnert $\mathrm{H}$, Brochner-Mortensen J, Gomis R, Andersen S, Arner P: The effect of irbesartan on the development of diabetic nephropathy in patients with type 2 diabetes. N Engl J Med 2001;345:870-878.

4 Viberti G, Wheeldon NM: Microalbuminuria reduction with valsartan in patients with type 2 diabetes mellitus: a blood pressure-independent effect. Circulation 2002; 106:672-678.

5 Lewis EJ, Hunsicker LG, Clarke WR, Berl T, Pohl MA, Lewis JB, Ritz E, Atkins RC, Rohde $\mathrm{R}, \mathrm{Raz}$ I: Renoprotective effect of the angiotensin-receptor antagonist irbesartan in patients with nephropathy due to type 2 diabetes. N Engl J Med 2001;345:851-860.

-6 Brenner BM, Cooper ME, de Zeeuw D, Keane WF, Mitch WE, Parving HH, Remuzzi G, Snapinn SM, Zhang Z, Shahinfar S: Effects of losartan on renal and cardiovascular outcomes in patients with type 2 diabetes and nephropathy. N Engl J Med 2001;345: 861-869.

$\checkmark 7$ Matsubara H, Inada M: Molecular insights into angiotensin II type 1 and type 2 receptors: expression, signaling and physiological function and clinical application of its antagonists. Endocr J 1998;45:137-150.

$\checkmark 8$ Matsubara H, Sugaya T, Murasawa S, Nozawa Y, Mori Y, Masaki H, Maruyama K, Tsutumi Y, Shibasaki Y, Moriguchi Y, Tanaka Y, Iwasaka T, Inada M: Tissue-specific expression of human angiotensin II $\mathrm{AT}_{1}$ and $\mathrm{AT}_{2}$ receptors and cellular localization of subtype mRNAs in adult human renal cortex using in situ hybridization. Nephron 1998;80:25-34

-9 Goldberg MR, Bradstreet TE, McWilliams EJ, et al: Biochemical effects of losartan, a nonpeptide angiotensin ii receptor antagonist, on the renin-angiotensin-aldosterone system in hypertensive patients. Hypertension 1995;25:37-46.

- 10 Berry C, Touyz R, Dominiczak AF, Webb RC, Johns DG: Angiotensin receptors: signaling, vascular pathophysiology, and interactions with ceramide. Am J Physiol Heart Circ Physiol 2001;281:H2337-H2365.
1 Sampson AK, Moritz KM, Jones ES, Flower RL, Widdop RE, Denton KM: Enhanced angiotensin II type 2 receptor mechanisms mediate decreases in arterial pressure attributable to chronic low-dose angiotensin II in female rats. Hypertension 2008;52:666-671.

12 Wu L, Iwai M, Nakagami H, Li Z, Chen R, Suzuki J, Akishita M, de Gasparo M, Horiuchi M: Roles of angiotensin II type 2 receptor stimulation associated with selective angiotensin II type 1 receptor blockade with valsartan in the improvement of inflammationinduced vascular injury. Circulation 2001; 104:2716-2721.

13 Fujii H, Kono K, Nakai K, Goto S, Komaba H, Hamada Y, Shinohara M, Kitazawa R, Kitazawa S, Fukagawa M: Oxidative and nitrosative stress and progression of diabetic nephropathy in type 2 diabetes. Am J Nephrol 2010;31:342-352.

14 Steffes MW, Bilous RW, Sutherland DE, Mauer SM: Cell and matrix components of the glomerular mesangium in type I diabetes. Diabetes 1992;41:679-684.

15 Goodfriend TL, Elliott ME, Catt KJ: Angiotensin receptors and their antagonists. N Engl J Med 1996;334:1649-1654.

-16 Siragy HM, Howell NL, Ragsdale NV, Carey RM: Renal interstitial fluid angiotensin. Modulation by anesthesia, epinephrine, sodium depletion, and renin inhibition. Hypertension 1995;25:1021-1024.

17 Sechi LA, Grady EF, Griffin CA, Kalinyak JE, Schambelan M: Distribution of angiotensin II receptor subtypes in rat and human kidney. Am J Physiol 1992;262:F236-F240.

18 Lafayette RA, Mayer G, Park SK, Meyer TW: Angiotensin II receptor blockade limits glomerular injury in rats with reduced renal mass. J Clin Invest 1992;90:766-771.

19 Plum J, Bunten B, Nemeth R, Grabensee B: Effects of the angiotensin II antagonist valsartan on blood pressure, proteinuria, and renal hemodynamics in patients with chronic renal failure and hypertension. J Am Soc Nephrol 1998;9:2223-2234.

20 Miyata N, Park F, Li XF, Cowley AW Jr: Distribution of angiotensin $\mathrm{AT}_{1}$ and $\mathrm{AT}_{2}$ receptor subtypes in the rat kidney. Am J Physiol 1999;277:F437-F446.
21 Ozono R, Wang ZQ, Moore AF, Inagami T, Siragy HM, Carey RM: Expression of the subtype 2 angiotensin $\left(\mathrm{AT}_{2}\right)$ receptor protein in rat kidney. Hypertension 1997;30:12381246

22 Suzuki K, Han GD, Miyauchi N, Hashimoto T, Nakatsue T, Fujioka Y, Koike H, Shimizu F, Kawachi H: Angiotensin II type 1 and type 2 receptors play opposite roles in regulating the barrier function of kidney glomerular capillary wall. Am J Pathol 2007;170:18411853.

23 Reudelhuber TL: The continuing saga of the $\mathrm{AT}_{2}$ receptor: a case of the good, the bad, and the innocuous. Hypertension 2005; 46 :12611262.

24 Pettersson-Fernholm K, Frojdo S, Fagerudd J, Thomas MC, Forsblom C, Wessman M, Groop $\mathrm{PH}$ : The $\mathrm{AT}_{2}$ gene may have a genderspecific effect on kidney function and pulse pressure in type I diabetic patients. Kidney Int 2006;69:1880-1884.

25 Nishikawa T, Edelstein D, Du XL, Yamagishi S, Matsumura T, Kaneda Y, Yorek MA, Beebe D, Oates PJ, Hammes HP, Giardino I, Brownlee M: Normalizing mitochondrial superoxide production blocks three pathways of hyperglycaemic damage. Nature 2000;404: 787-790.

-26 Nishikawa T, Sasahara T, Kiritoshi S, Sonoda K, Senokuchi T, Matsuo T, Kukidome D, Wake N, Matsumura T, Miyamura N, Sakakida M, Kishikawa H, Araki E: Evaluation of urinary 8-hydroxydeoxy-guanosine as a novel biomarker of macrovascular complications in type 2 diabetes. Diabetes Care 2003; 26:1507-1512.

-27 Nagasu H, Satoh M, Yorimitsu D, Tomita N, Sasaki T, Kashihara N: Comparison of combination therapy of olmesartan plus azelnidipine or hydrochlorothiazide on renal and vascular damage in SHR/NDmcr-cp rats. Kidney Blood Press Res 2011;34:87-96.

28 Takao T, Horino T, Kagawa T, Matsumoto R, Inoue $\mathrm{K}$, Taguchi $\mathrm{T}$, Morita $\mathrm{T}$, Iwasaki $\mathrm{Y}$, Hashimoto K, Terada Y: Effects of angiotensin II type 1 receptor blocker on albumininduced cell damage in human renal proximal tubular epithelial cells. Am J Nephrol 2009;29:102-108. 